\title{
ICH Guidelines-compliant HPLC-UV Method for Pharmaceutical Quality Control and Therapeutic Drug Monitoring of the Multi-targeted Tyrosine Kinase Inhibitor Pazopanib
}

\author{
Nasr Y. Khalil, Ibrahim A. Darwish*, Munif F. Alshammari and Tanveer A. Wani \\ Department of Pharmaceutical Chemistry, College of Pharmacy, King Saud University, P.O. Box 2457, Riyadh 11451, Saudi Arabia.
}

Received 14 December 2016, revised 19 February 2017, accepted 20 February 2017.

\begin{abstract}
In this study, an HPLC method with ultraviolet (UV) detection was developed and validated for determination of pazopanib (PAZ), a multi-targeted tyrosine kinase (TK) inhibitor in bulk drug, tablets formulation, and in human plasma. Oxamniquine (OXA) was used as internal standard (IS). The analytical column used for the separation was Nucleosil CN with dimensions (i.d. $250 \times 4.6 \mathrm{~mm}$ and particle size $5 \mu \mathrm{m}$ ). The separation was carried out in isocratic mode with mobile phase constituting acetonitrile:100 mM sodium acetate buffer $(\mathrm{pH} \mathrm{4.5);40:60,} \mathrm{v/v.} \mathrm{The} \mathrm{developed} \mathrm{method} \mathrm{was} \mathrm{linear} \mathrm{in} \mathrm{the} \mathrm{concentration} \mathrm{range} \mathrm{of}$ 2-12 $\mu \mathrm{g} \mathrm{mL}^{-1}$ and had a correlation coefficient $(\mathrm{r}=0.9998, \mathrm{n}=6)$. The limits of detection and quantitation (LOD and LOQ) were 0.27 and $0.82 \mu \mathrm{g} \mathrm{mL}^{-1}$, respectively. The relative standard deviations for the inter- and intra-assay precisions were below $3.61 \%$ and the accuracy of the method was $96.69-104.15 \%$. The degradation products were resolved from the intact drug, proving the stability-indicating property of the proposed method. The recovery values were $100.17-103.98 \%( \pm 1.81-4.02)$ for determination of PAZ in human plasma. The results indicated the versatility of the new method in estimation of PAZ during pharmaceutical quality control (QC) and therapeutic drug monitoring (TDM).
\end{abstract}

KEYWORDS

Tyrosine kinase inhibitors, pazopanib, HPLC, UV detection, quality control, therapeutic drug monitoring.

\section{Introduction}

An important role of vascular endothelial growth factor receptor (VEGF) in quite a few tumor forms has been reported. ${ }^{1-3}$ The dysregulation of platelet derived growth factor (PDGF) ${ }_{-}^{4}$ and epidermal growth factor (EGF) ${ }^{5}$ also play an important role in propagation of tumor cell. Pazopanib (PAZ; GW-786034) chemically known as 5-(\{4-[(2,3-Dimethyl-2H-indazol-6-yl) (methyl) amino]-2-pyrimidinyl\}amino)-2-methylbenzene-sulfonamide (Fig. 1) is tyrosine kinase inhibitor (multi-targeted and orally active). The targets for PAZ are VEGFR-1, -2 , and -3, PDGFR- $\alpha$, PDGFR- $\beta$, c-Kit and act by inhibiting auto-phosphorylation of growth factor receptor (intracellular TK domain). PAZ competes with ATP to bind to the intracellular TK domain thus, blocking downstream signal transduction. ${ }^{6}$ The recommended dose of PAZ is not more than $800 \mathrm{mg}$ once daily for treatment of soft tissue sarcoma or renal cell carcinoma. Pharmacokinetic studies have revealed peak plasma concentration of $58.1 \mu \mathrm{g} \mathrm{mL}^{-1}$ and mean AUC of $1037 \mu \mathrm{g} \mathrm{h} \mathrm{mL}^{-1}$ for PAZ after a dose of $50-2000 \mathrm{mg}$. The absorption of PAZ in cancer patients is slow and the bioavailability of $800 \mathrm{mg}$ tablet in these patients is $21 \%$. The PAZ accumulates after continuous once daily dosing for 22 days and the drug is present in the systemic circulation as intact PAZ and not as metabolites of PAZ. PAZ is $99 \%$ plasma protein bound and is eliminated mainly through feces and around $4 \%$ through renal route. ${ }^{7}$

Environmental conditions (e.g. temperature, humidity, etc.) that vary during manufacturing, transportation, distribution

* To whom correspondence should be addressed. E-mail: idarwish@ ksu.edu.sa<smiles>Cc1ccc(Nc2nccc(N(C)c3ccc4c(C)n(C)nc4c3)n2)cc1S(N)(=O)=O</smiles>

Pazopanib (PAZ)<smiles>CC(C)NCC1CCc2cc(CO)c([N+](=O)[O-])cc2N1</smiles>

Oxamniquine (OXA)

Figure 1 Chemical structure of pazopanib (PAZ) and oxamniquine (OXA). and storage of drugs have great effect on their potency and therefore the quality of the pharmaceutical product (Votrient ${ }^{\circledR}$ tablets; Novartis, USA). As well, impurities and/or degradation products present in the drug substance can alter the pharmacological behavior of the active pharmaceutical ingredient. ${ }^{4-7}$ 
Several adverse effects like eye disorders (e.g. retinal detachment/tear) and gastrointestinal disorders (e.g. pancreatitis) ${ }^{7}$ have been reported with votrient ${ }^{\circledast}$ tablets during the postmarketing surveillance. These adverse effects can also be attributed to the degradation products of PAZ; therefore, necessitating stability testing of the active PAZ substance. Saudi Arabian weather conditions are highly variable and thus could affect the quality of PAZ. PAZ tablets are imported from outside Saudi Arabia and therefore may be exposed to great climatic variation from manufacturing to national distribution. The stability testing can used to optimize for the appropriate packing process, determining storage conditions, shelf life and expiry date..$^{8-13}$ These reasons warrant the need of method for assessing the quality control (QC) of PAZ-containing tablets.

An exposure-response relationship has been observed during therapy with PAZ.? Therefore, therapeutic drug monitoring (TDM) of PAZ could be a valuable tool in clinical practice. For pharmaceutical QC of PAZ and its TDM, a validated reliable analytical method is necessary. The reported methods for determination of PAZ are limited ${ }^{14-18}$ and mostly suffer from major drawbacks such as: (1) their applications are limited to the bulk drug and/or dosage forms, ${ }^{14-16}$ but not applicable to plasma samples; (2) the method devoted to analysis of plasma samples is relying on intensive and costly instrumental techniques such as liquid chromatography-tandem mass spectrometry; ${ }^{18}$ which is not available in most QC and/or clinical laboratories. In this study, an HPLC method based on UV detection was developed and validated for stability testing of PAZ and its therapeutic drug monitoring. The developed method was selective and sensitive and it fulfilled the requirements of the International Conference on Harmonization $(\mathrm{ICH})$ guidelines for validation of analytical procedures.

\section{Experimental}

\subsection{Materials}

Pazopanib (PAZ) standard drug was provided as gift sample by Saudi Food \& Drug Authority Laboratories (Riyadh, Saudi Arabia). Oxamniquine (OXA) was purchased from Sigma-Aldrich Corporation (Saint Louis, CA, USA). Votrient ${ }^{\circledR}$ film-coated tablets (GlaxoSmithKline, Philadelphia, PA, USA) obtained from local market contained $200 \mathrm{mg}$ of PAZ per tablet as per the label claim. King Khalid University Hospital (Riyadh, Saudi Arabia) provided the human plasma and the plasma was stored at $-20^{\circ} \mathrm{C}$ till analysis. HPLC grade solvents obtained from (Merck, Darmstadt, Germany) were used for analysis. Millipore Milli- $Q^{\circledR}$ UF Plus apparatus (Millipore, Molsheim, France) was used to obtain ultra-pure water for the analysis.

\subsection{Chromatographic System and Conditions}

HPLC system from Shimadzu controlled by 'LC solution' software (Shimadzu Corporation, Kyoto, Japan) equipped with pump LC-20AD VP, auto-sampler SIL-20A, co-sense BA LC system, column oven CTO-20A, UV-VIS detector SPD-20A and system controller CBM-20A. The analytical column used for the separation was nucleosil CN manufactured by Macherey-Nagel $\mathrm{GmbH}$ (Düren, Germany) with dimensions (i.d. $250 \times 4.6 \mathrm{~mm}$ and particle size $5 \mu \mathrm{m}$ ). The analysis was performed under constant column temperature of $25 \pm 2{ }^{\circ} \mathrm{C}$. The separation was carried out in isocratic mode with mobile phase constituting acetonitrile:100 mM sodium acetate buffer ( $\mathrm{pH} 4.5) ; 40: 60, \mathrm{v} / \mathrm{v}$. Prior to use the mobile phase was filtered using millipore $0.45 \mu \mathrm{m}$ filter and degassed on an ultrasonic bath. After optimization the ideal flow rate was found to be $1.2 \mathrm{~mL} \mathrm{~min}^{-1}$ and the PAZ was detected at $270 \mathrm{~nm}$. Samples of $20 \mu \mathrm{L}$ were injected into the HPLC system during the analysis.

\subsection{Preparation of PAZ Standard and Sample Solutions}

A stock solution of $1 \mathrm{mg} \mathrm{mL} L^{-1}$ in methanol was prepared by accurately weighing $(5 \mathrm{mg})$ of PAZ and dissolving in $5 \mathrm{~mL}$ methanol. Working standard of $200 \mathrm{mg} \mathrm{mL}^{-1}$ was obtained by diluting the stock solution with methanol. The tablet samples $\left(\right.$ Votrien $t^{\oplus}$ ) were prepared by weighing 10 tablets, calculating their average weight and then crushing them to fine powder. $25 \mathrm{mg}$ equivalent powder of PAZ was diluted with methanol to obtain a solution of $1 \mathrm{mg} \mathrm{mL}^{-1}$. The resulting solution was filtered through $0.45 \mu \mathrm{m}$ membrane filter. The stock solution was diluted to obtain concentration ranging from $2-12 \mu \mathrm{g} \mathrm{mL}^{-1}(2,4,6,8,10$, $12 \mu \mathrm{g} \mathrm{mL}^{-1}$ ) and were subjected to analysis by the proposed method.

\subsection{Preparation of OXA Internal Standard Solution}

Stock solution of OXA $1 \mathrm{mg} \mathrm{mL}^{-1}$ in methanol was prepared by dissolving $25 \mathrm{mg}$ of OXA in $25 \mathrm{~mL}$ of methanol. The working solution of OXA $200 \mu \mathrm{g} \mathrm{mL}^{-1}$ was prepared from the stock solution.

\subsection{Forced Degradation}

\subsubsection{Acid and Alkali Hydrolysis}

A $500 \mu \mathrm{L}$ aliquot of PAZ working standard $\left(200 \mu \mathrm{g} \mathrm{mL}^{-1} \mathrm{l}\right)$ were pipetted into $10 \mathrm{~mL}$ volumetric flasks $(\mathrm{n}=10)$ and were added with $8.5 \mathrm{~mL}$ water. The flasks were separated into two groups of five each and were added with either $1 \mathrm{~mL}$ of $10 \mathrm{~N}$ hydrochloric acid or $10 \mathrm{~N}$ sodium hydroxide. The resulting solutions were initially heated for $5 \mathrm{~min}$ on hot plate and then transferred to a water bath $\left(70{ }^{\circ} \mathrm{C}\right)$. The samples were removed from the water bath after $1 \mathrm{~h}$ and allowed to cool down to room temperature $\left(25 \pm 2{ }^{\circ} \mathrm{C}\right)$. The samples were then neutralized either with acid or base (equivalent amount) and $20 \mu \mathrm{L}$ of these neutralized samples were injected into the HPLC system.

\subsubsection{Oxidation}

A $500 \mu \mathrm{L}$ aliquot of PAZ working standard $\left(200 \mu \mathrm{g} \mathrm{mL}^{-1}\right)$ were pipetted into $10 \mathrm{~mL}$ volumetric flasks $(n=5)$ and were added with $7.5 \mathrm{~mL}$ water. These flasks were added with $2 \mathrm{~mL}$ of $30 \%$ hydrogen peroxide solution. The samples flasks were placed inside a water bath $\left(70^{\circ} \mathrm{C}\right)$. The samples were withdrawn from the flasks in water bath at intervals of $15,30,60,120,180,240$, and $300 \mathrm{~min}$. After withdrawing the samples were allowed to cool to the room temperature $\left(25 \pm 2{ }^{\circ} \mathrm{C}\right)$ and then $20 \mu \mathrm{L}$ were injected in to the HPLC system.

\subsection{Construction of Calibration Curve for Analysis of Plasma Samples}

Blank human plasma was spiked with varying PAZ and OXA (internal standard) fixed concentration of $10 \mu \mathrm{g} \mathrm{mL}^{-1}$ to prepare the calibration standards in the range $2-12 \mu \mathrm{g} \mathrm{mL}^{-1}$. Aliquots of $500 \mu \mathrm{L}$ of spiked plasma were added to $500 \mu \mathrm{L}$ of methanol, vortexed for $30 \mathrm{~s}$ and then centrifuged at $13000 \mathrm{rpm}$ for $20 \mathrm{~min}$. The supernatant was pipetted out and filtered through $0.2 \mu \mathrm{m}$ millipore syringe filters. A $20 \mu \mathrm{L}$ aliquot of the filtered sample was injected into the HPLC system for analysis. The calibration curve contained six calibration points and the calibration plot was constructed as peak area ratio of PAZ to OXA ( $y$-axis) versus PAZ concentration ( $x$-axis). Each calibration standard was analyzed three times and the slope, intercept and correlation coefficient (r) calculated. 


\section{Results and Discussion}

\subsection{Method Development and Chromatographic Condition Optimization}

HPLC is widely used in quality control, pharmaceutical analysis and clinical settings as it provides acceptable sensitivity, more convenient and cheaper. PAZ contains a chromophore center (Fig. 1) and therefore, a method based on UV detection was developed and validated for estimation of PAZ in bulk and dosage form for QC analysis. The developed method was also validated for estimation of PAZ in plasma for TDM, pharmacokinetic and toxicokinetic analysis. The OXA (Fig. 1) was selected as internal standard on the basis that it also shows maximum absorption in the same region as PAZ (270 nm) (Fig. 2). It was also determined by the preliminary experiments that the peaks (PAZ and OXA) are resolved (Fig. 3B).

The chromatographic conditions were optimized and included the selection of mobile phase and column. Several mobile phases systems and columns were studied during the analysis and the most appropriate mobile phase was found to be acetonitrile: $100 \mathrm{mM}$ sodium acetate buffer $(40: 60, \mathrm{v} / \mathrm{v})$, adjusted to $\mathrm{pH}$ 4.5 with $100 \%$ acetic acid. The nucleosil CN with dimensions (i.d. $250 \times 4.6 \mathrm{~mm}$ and particle size $5 \mu \mathrm{m}$ ) manufactured by Macherey-Nagel GmbH (Düren, Germany) analytical column provided the most acceptable separation. The optimum flow rate for the mobile phase was found to be $1.2 \mathrm{~mL} \mathrm{~mL}^{-1}$ an isocratic mode. The column temperature $\left(25 \pm 2{ }^{\circ} \mathrm{C}\right)$ during the analysis was not varied during analysis. The total run time under these optimized conditions was $7 \mathrm{~min}$ and the retention time for PAZ was found to be $5.55 \pm 0.04$ and that for the OXA was found to be $3.70 \pm 0.02 \mathrm{~min}(\mathrm{n}=5)$ (Fig. 3). The tabular format for the chromatographic conditions is presented in Table 1.

\subsection{Method Validation}

\subsubsection{Linearity and Sensitivity}

Three different calibration curves were generated independently and with the 6-concentration standards $2,4,6,8,10,12 \mu \mathrm{g} \mathrm{mL}^{-1}$ and each standard was run thrice during each run. The least-square method was used for the regression analysis and the standard deviation of each calibration standard (triplicate) was less than $2 \%$. The generated equation for the calibration curve was: $\mathrm{Y}=-0.042+0.1746 \mathrm{C}(\mathrm{r}=0.9998)$. $\mathrm{Y}$ represents the relative detector signal, $\mathrm{C}$ represents the concentration of PAZ and the correlation coefficient is represented by r. Signal-tonoise ratio ${ }^{19}$ was used for determination of limit of detection

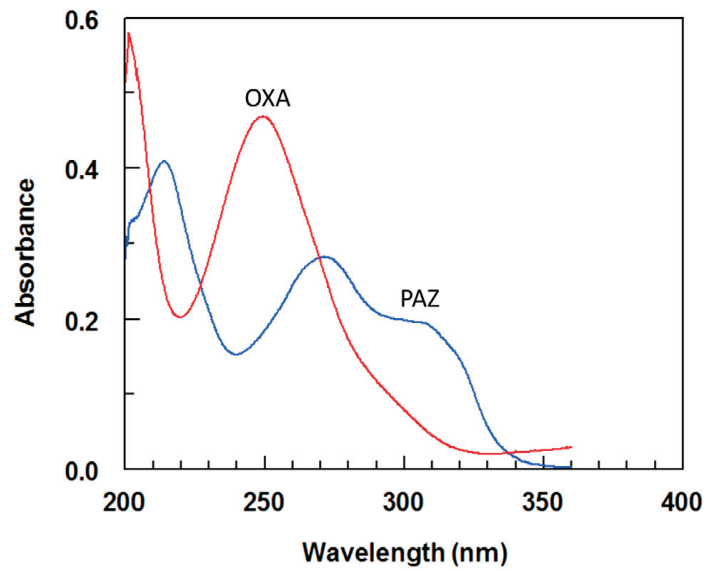

Figure 2 Absorption spectra of pazopanib (PAZ) and oxamniquine (OXA) against methanol. Concentrations of both PAZ and OXA were $10 \mu \mathrm{g} \mathrm{mL}^{-1}$ in methanol.
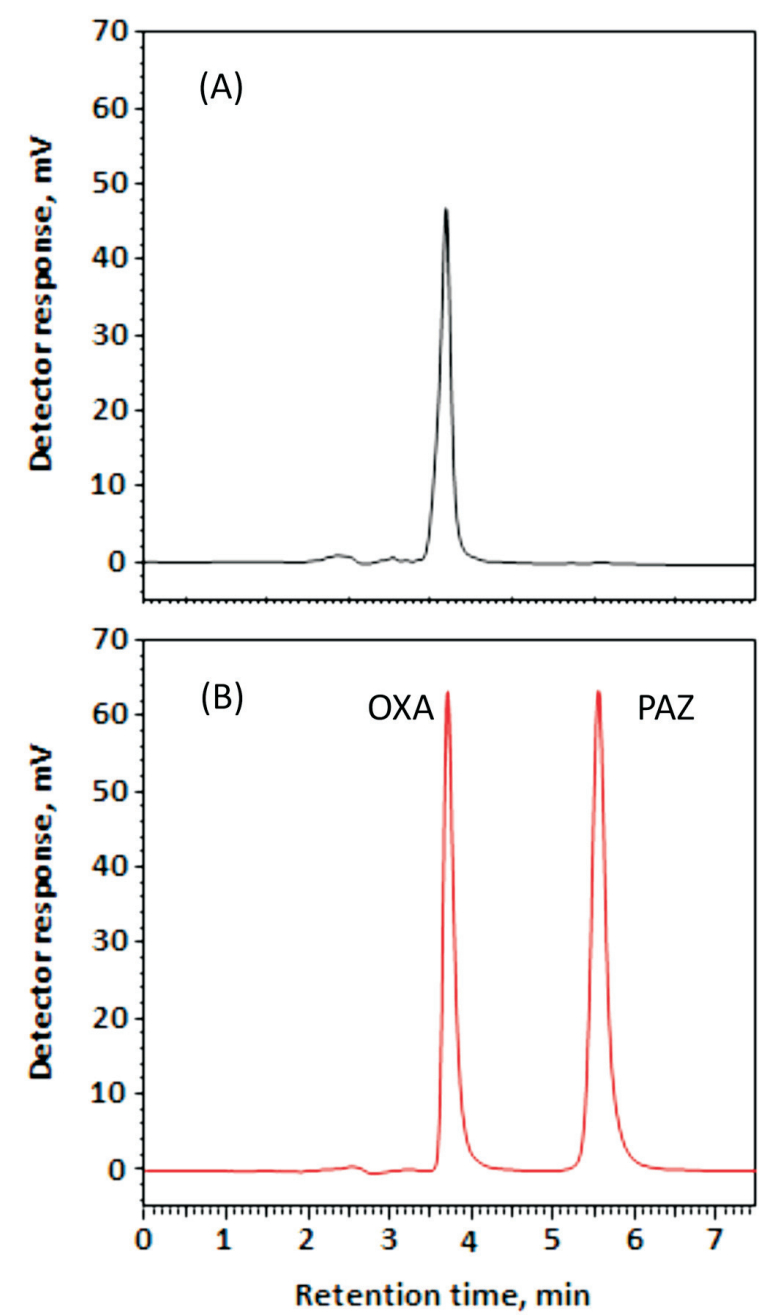

Figure 3 Representative chromatogram of $10 \mu \mathrm{g} \mathrm{mL}^{-1}$ of standard solution of the internal standard, OXA (A) and a mixture solution containing $10 \mu \mathrm{g} \mathrm{mL}^{-1}$ of both standard PAZ and OXA (B).

(LOD) and limit of quantitation (LOQ). The LOD and LOQ values were 0.27 and $0.82 \mu \mathrm{g} \mathrm{mL}^{-1}$, respectively.

\subsubsection{Precision and Accuracy}

ICH guidelines were followed to measure the precision of the developed method. Five injections of the six calibration standard $\left(2,4,6,8,10\right.$ and $\left.12 \mu \mathrm{g} \mathrm{mL}^{-1}\right)$ were run repeatedly to determine the intra-assay precision. The relative standard deviation (RSD)

Table 1 Chromatographic parameters for PAZ and OXA by the proposed HPLC method.

\begin{tabular}{ll}
\hline Parameter & Value \\
\hline Retention time of PAZ & $5.55 \pm 0.04$ \\
Retention time of OXA (IS) & $3.70 \pm 0.02$ \\
Capacity factor & 2.67 \\
Resolution & 2.80 \\
Peak asymmetry at $10 \%$ peak height & 1.36 \\
Number of theoretical plates & 3657 \\
Height equivalent to theoretical plate $/ \mu \mathrm{m}$ & 273 \\
Correlation coefficient $/ \mathrm{r}$ & 0.9998 \\
Slope $(\mathrm{b}) \pm \mathrm{SD}$ & 0.1746 \\
Intercept $(\mathrm{a}) \pm \mathrm{SD}$ & -0.042 \\
LOD $/ \mu \mathrm{g} \mathrm{mL} \mathrm{m}^{-1}$ & 0.27 \\
LOQ $/ \mu \mathrm{g} \mathrm{mL} \mathrm{m}^{-1}$ & 0.82 \\
Linear range $/ \mu \mathrm{g} \mathrm{mL} \mathrm{mL}^{-1}$ & $2-12$ \\
\hline
\end{tabular}


Table 2 Precision and accuracy data for analysis of PAZ by the proposed HPLC method.

\begin{tabular}{lccc}
\hline $\begin{array}{l}\text { Nominal } \\
\text { concentration } \\
/ \mu \mathrm{g} \mathrm{mL}^{-1}\end{array}$ & $\begin{array}{c}\text { Measured } \\
\text { concentration } \\
/ \mu \mathrm{g} \mathrm{mL}^{-1}\end{array}$ & $\begin{array}{c}\text { Recovery } \\
/ \%\end{array}$ & $\begin{array}{c}\text { RSD } \\
\text { Within run }\end{array}$ \\
2 & 2.08 & 104.15 & 1.59 \\
4 & 4.04 & 101.02 & 0.51 \\
6 & 5.89 & 98.09 & 0.27 \\
8 & 7.90 & 98.79 & 0.54 \\
10 & 9.96 & 99.61 & 1.87 \\
12 & 12.13 & 101.09 & 3.61 \\
Between runs & & & \\
2 & 2.00 & 99.78 & 0.11 \\
4 & 3.88 & 96.97 & 0.14 \\
6 & 5.80 & 96.69 & 0.09 \\
8 & 7.75 & 96.85 & 0.12 \\
10 & 9.78 & 97.82 & 0.10 \\
12 & 11.90 & 99.14 & 0.07 \\
\hline
\end{tabular}

calculated for the intra-assay precision did not exceed $3.61 \%$ (Table 2). Inter- assay precision for PAZ at concentration levels of $\left(2,4,6,8,10\right.$ and $\left.12 \mu \mathrm{g} \mathrm{mL}^{-1}\right)$ was determined by repeating the analysis of the same concentration thrice in three different runs. The RSD values of inter-assay precision did not exceed $0.14 \%$, proving the satisfactory precision of the method. ${ }^{19}$

Accuracy of the method was determined by spiking known concentrations of PAZ $\left(2,4,6,8,10\right.$ and $\left.12 \mu \mathrm{g} \mathrm{mL}^{-1}\right)$ to placebo matrix for tablets. Five replicates for each concentration were injected and the concentrations were back calculated from the calibration curve. The concentrations recovered are presented as percentage of the nominal concentration and were in the range 96.69-104.15\% (Table 3). The developed method showed acceptable accuracy. ${ }^{19}$

\subsubsection{Robustness and Ruggedness}

The ruggedness of the method was evaluated by altering the most important optimized chromatographic parameters within the range $1-10 \%$ and not interfering with other parameters. The parameters that were studied for the robustness included mobile phase composition, flow rate of mobile phase, change in $\mathrm{pH}$, and column temperature. The results obtained indicated the robustness of the method and minute changes within $10 \%$ did not significantly alter the PAZ estimation.

The method for PAZ was tested for its robustness using mobile phase from different manufacturers and the retention time did not change significantly with the mobile phases from different manufacturers. The relative standard deviation recorded was $0.29-1.85 \%$ inferring the methods ruggedness.

Table 3 Application of the proposed HPLC method in the determination of PAZ in Votrient ${ }^{\circledast}$ tablets.

\begin{tabular}{ccr}
\hline $\begin{array}{c}\text { Taken concentration } \\
/ \mu \mathrm{g} \mathrm{mL}^{-1}\end{array}$ & $\begin{array}{c}\text { Measured concentration } \\
/ \mu \mathrm{g} \mathrm{mL}^{-1}\end{array}$ & $\begin{array}{c}\text { Recovery } \\
/ \% \pm \mathrm{RSD}\end{array}$ \\
\hline 2 & 1.93 & $95.92 \pm 0.53$ \\
4 & 3.99 & $99.87 \pm 1.14$ \\
6 & 5.82 & $97.05 \pm 2.21$ \\
8 & 7.86 & $98.29 \pm 0.22$ \\
10 & 9.91 & $99.15 \pm 0.78$ \\
12 & 12.26 & $102.19 \pm 0.49$ \\
\hline
\end{tabular}

\subsubsection{Sample Solution Stability}

In order to check the bench top stability of the drug during experimentation, the drug solution $\left(8 \mu \mathrm{g} \mathrm{mL}^{-1}\right)$ was kept was subjected to analysis at 24,48 and $72 \mathrm{~h}$ under normal laboratory conditions $\left(25 \pm 2{ }^{\circ} \mathrm{C}\right)$. The drug was also tested under refrigerated condition $\left(8 \pm 1{ }^{\circ} \mathrm{C}\right)$ after $72 \mathrm{~h}$ of storage. No significant change in the samples was found over the tested period indicating stability of the drug solution and the RSD for the samples stored at $\left(8 \pm 1{ }^{\circ} \mathrm{C}\right)$ and $\left(25 \pm 2{ }^{\circ} \mathrm{C}\right)$ was found to be $1.27 \%$ and $1.04 \%$, respectively.

\subsubsection{System Suitability}

The instrument was checked for system suitability prior to sample analysis. The parameters analyzed included retention factor $(\mathrm{K})$, repeated injections effect (similar to precision analysis), number of theoretical plates, tailing factor $(\mathrm{T})$ and peak resolution (Rs) for PAZ and OXA. Using a $10 \mu \mathrm{g} \mathrm{mL}^{-1}$ for PAZ the capacity factor was found to be 2.67 inferring that the PAZ peak is resolved efficiently from the void volume. A RSD of $0.25 \%$, indicated excellent injection repeatability. Peak symmetry of 1.36 indicated good peak symmetry. The PAZ and OXA were resolved properly indicated by the peak resolution of 2.80 . The number of theoretical plates using Nucleosil $\mathrm{CN}$ with dimensions (i.d. $250 \times 4.6 \mathrm{~mm}$ and particle size $5 \mu \mathrm{m}$ ) was found to be 3657 establishing adequate column efficacy. The results obtained from the analysis by the proposed HPLC method indicate the efficiency of the method for the routine analysis PAZ.

\subsection{Stability-indicating Study}

The ICH guidelines ${ }^{20}$ recommends stress testing of drug substance to interpret the intrinsic stability of the API as the drug substance can pass through stressful situations during the manufacturing. Hydrolytic and oxidation tests are recommended by the ICH guidelines for stress testing. A method that can quantify drug as well as resolve its degradation products is identified as best stability-indicating method. PAZ was stress tested as described in the experimental section (acid hydrolysis, alkali hydrolysis and oxidation. Chromatograms from acid and alkali hydrolysis of PAZ indicate that no degradation of PAZ occurred under these conditions when matched with chromatograms of blank solutions (Figs. 4-5). However, post-oxidation hydrolysis degradation products could be seen in the chromatogram (Fig. 6). As is clear from the chromatogram that the degradation products could be separated completely from PAZ using the proposed method, establishing stability-indicating property of the proposed method. The kinetics of PAZ degradation in oxidative conditions was studied. Plot of time versus both peak areas of PAZ and their corresponding $\ln$ values is shown in Fig. 7. Straight line with good correlation coefficient (0.9986) was obtained from linear regression analysis of time-log peak area plot (Fig. 7). This confirmed that the oxidative degradation of PAZ behaved as first-order reaction..$^{21}$ The reaction rate constant (K) was calculated from the slope of the regression equation (Fig. 7); $\mathrm{K}=-$ slope $\times 2.303 .{ }^{21}$ The $\mathrm{K}$ value was calculated and found to be $6 \times 10^{-2} \mathrm{~min}^{-1}$ with $\mathrm{t}^{1 / 2}$ value of $11.15 \mathrm{~min}$.

\subsection{Selectivity of the Method}

PAZ and OXA were well separated under the optimized chromatographic conditions and the representative chromatograms are given in Fig. 3. The chromatogram obtained from analysis of Votrient ${ }^{\circledR}$ tablet solution spiked with OXA was identical to that of the standard solution indicating that the tablet excipients had no interference with the analysis. Thus, indicating selectivity of the method for quality control analysis of PAZ. 

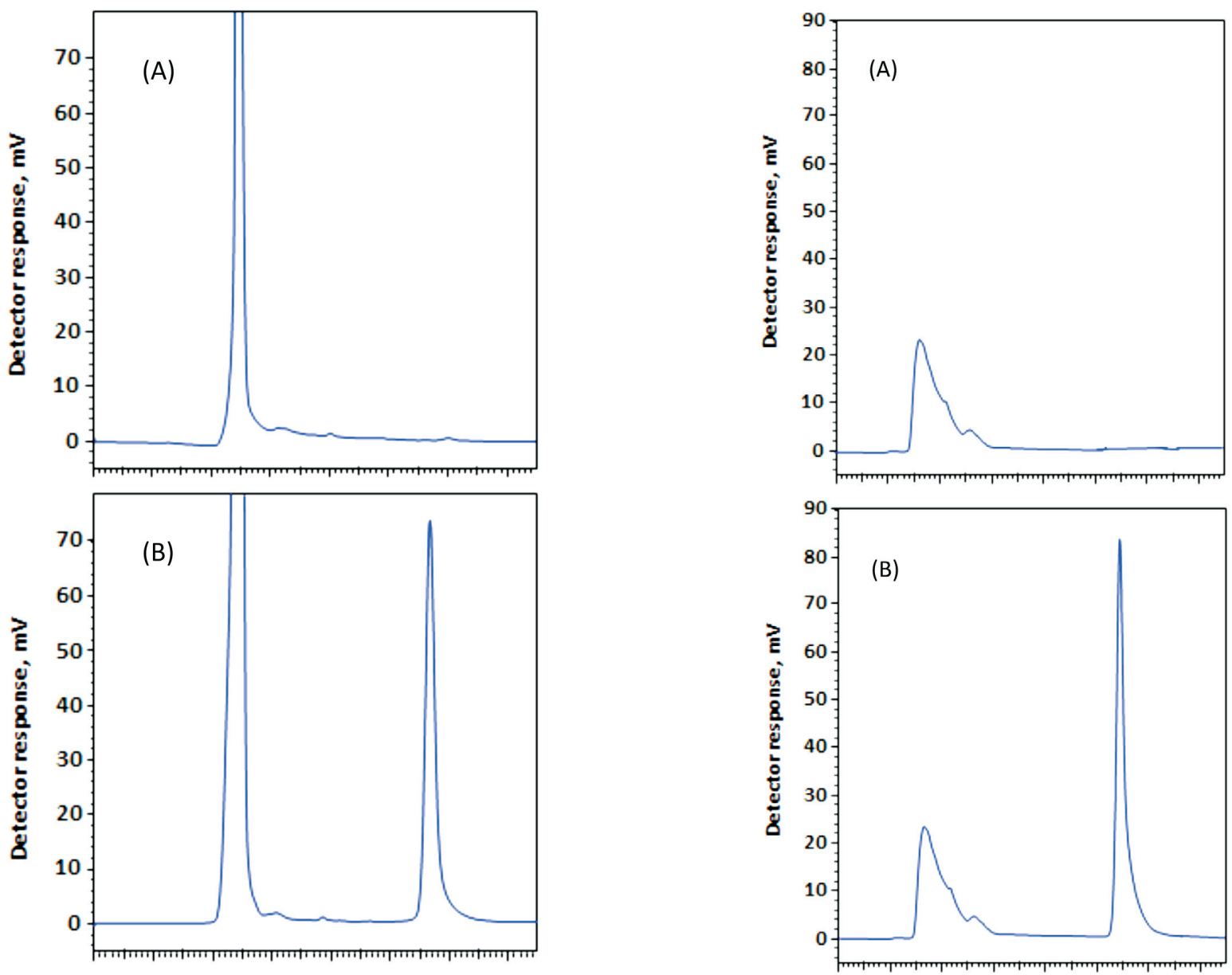

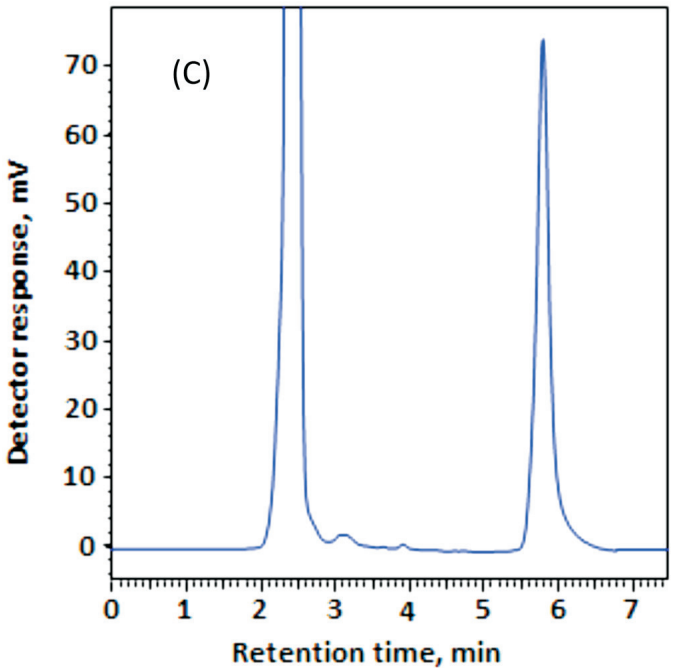

Figure 4 Acid stress testing of PAZ. Panel $\mathbf{A}$ is the blank $\mathrm{HCl}$ solution without PAZ. Panels B and C are PAZ standard solutions that have been subjected to $\mathrm{HCl}$ acid hydrolysis for $5 \mathrm{~min}$ and $1 \mathrm{~h}$ (in a water bath at $\left.70^{\circ} \mathrm{C}\right)$, respectively.

The developed methods selectivity was also accessed in plasma. Blank human plasma was used to access the selectivity and recognize the peaks due to the plasma constituents and their resolution from the peaks of PAZ and OXA (IS). Figure 8 represents the chromatograms obtained from the blank plasma, plasma spiked with OXA, and plasma spiked with both PAZ and OXA. As is evident from the chromatograms that the PAZ and OXA are completely separated from the endogenous plasma constituents, thus, indicating selectivity of the method in plasma.

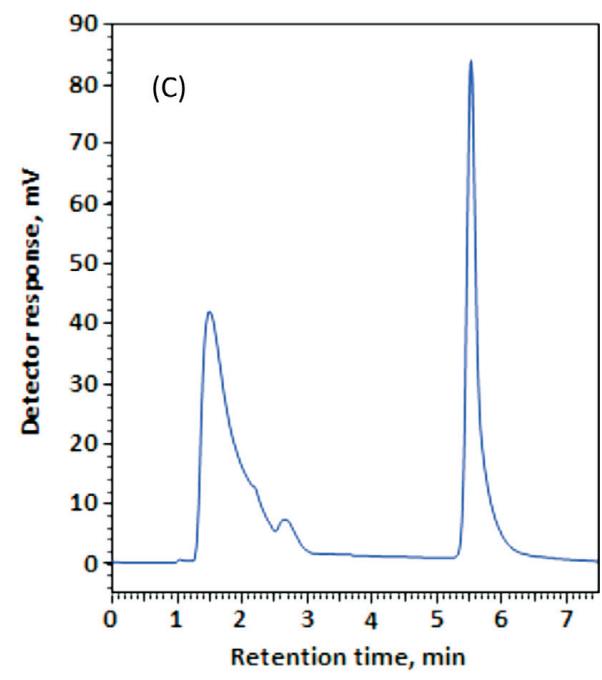

Figure 5 Alkali stress testing of PAZ. Panel A is the blank $\mathrm{NaOH}$ solution solution without PAZ. Panels B and C are PAZ standard solutions that have been subjected to $\mathrm{NaOH}$ hydrolysis for $5 \mathrm{~min}$ and $1 \mathrm{~h}$ (in a water bath at $\left.70^{\circ} \mathrm{C}\right)$, respectively.

\subsection{Applications of the Method}

The method was successfully applied for estimation of PAZ in Votrient $^{\circledR}$ tablets and human plasma. Varying concentrations of tablets solutions were taken and subjected to the analysis by the proposed method. Recovery values were $95.92-102.19 \%$ and the relative standard deviation (RSD) values were 0.22-2.21\% (Table 3) indicating the reliability of the method for quality control of PAZ in bulk and dosage form. As well, human plasma samples were spiked with varying PAZ concentrations (Table 4) within its reported therapeutic plasma levels, ${ }^{7,22}$ and the spiked 
samples were subjected to the analysis by the proposed method. The results were satisfactory in terms of the accuracy and precision as the recovery values were 100.17-103.98 \% and RSD did not exceed $4.02 \%$ (Table 4 ). These data indicate the applicability of the proposed HPLC method for the accurate determination of PAZ in plasma in bioequivalence and pharmacokinetic studies.
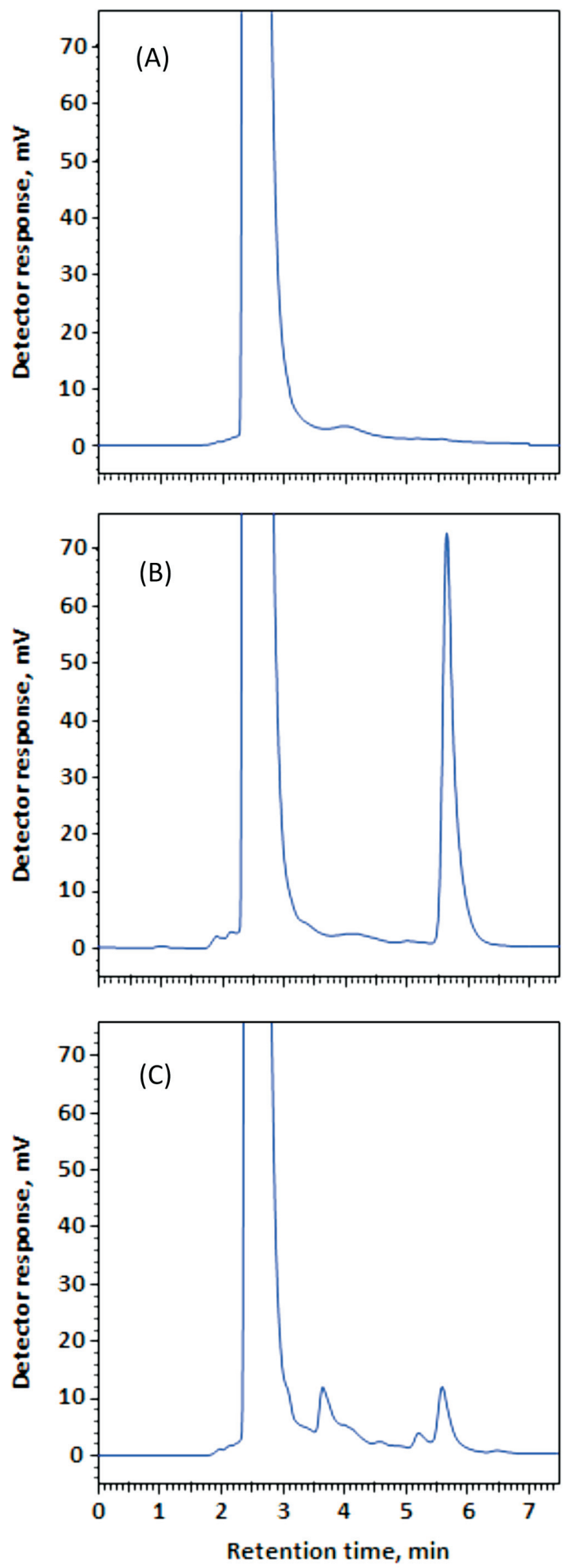

Figure 6 Oxidative stress testing of PAZ. Panel A is the chromatogram of blank hydrogen peroxide solution. Panel $\mathbf{B}$ is the chromatogram of a mixture of PAZ and hydrogen peroxide injected directly after mixing. Panel $\mathrm{C}$ is the chromatogram of a mixture of PAZ and hydrogen peroxide injected after incubation for $5 \mathrm{~h}$ in a water bath at $70^{\circ} \mathrm{C}$.

\section{Conclusion}

The present study represents the first report that deals with the development of an HPLC method with ultraviolet (UV) detection for determination of PAZ, a multi-targeted tyrosine kinase inhibitor in bulk drug, tablets formulation, and in human

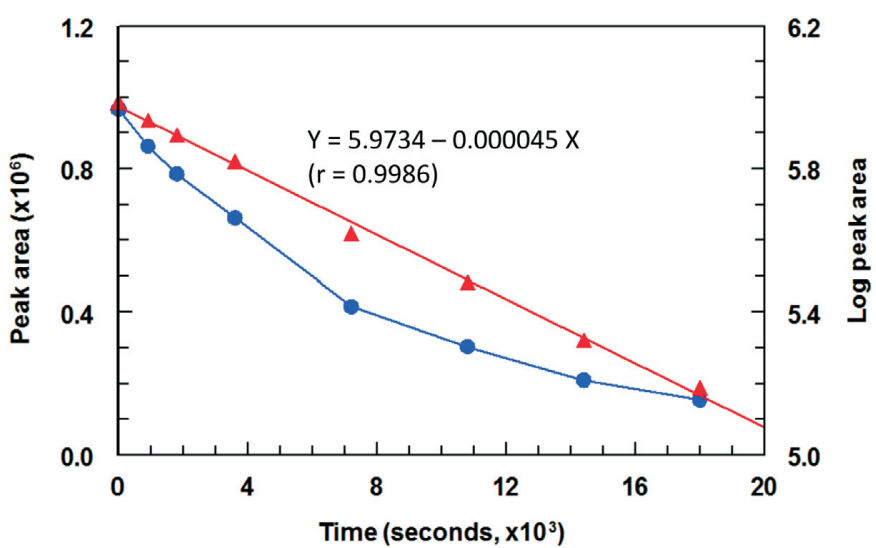

Figure 7 Kinetic study for stressed oxidation of PAZ. The time-peak area curve $(\bullet)$ and the linear plot of time-log peak area $(\boldsymbol{\Delta})$ with its fitting equation and correlation coefficient.
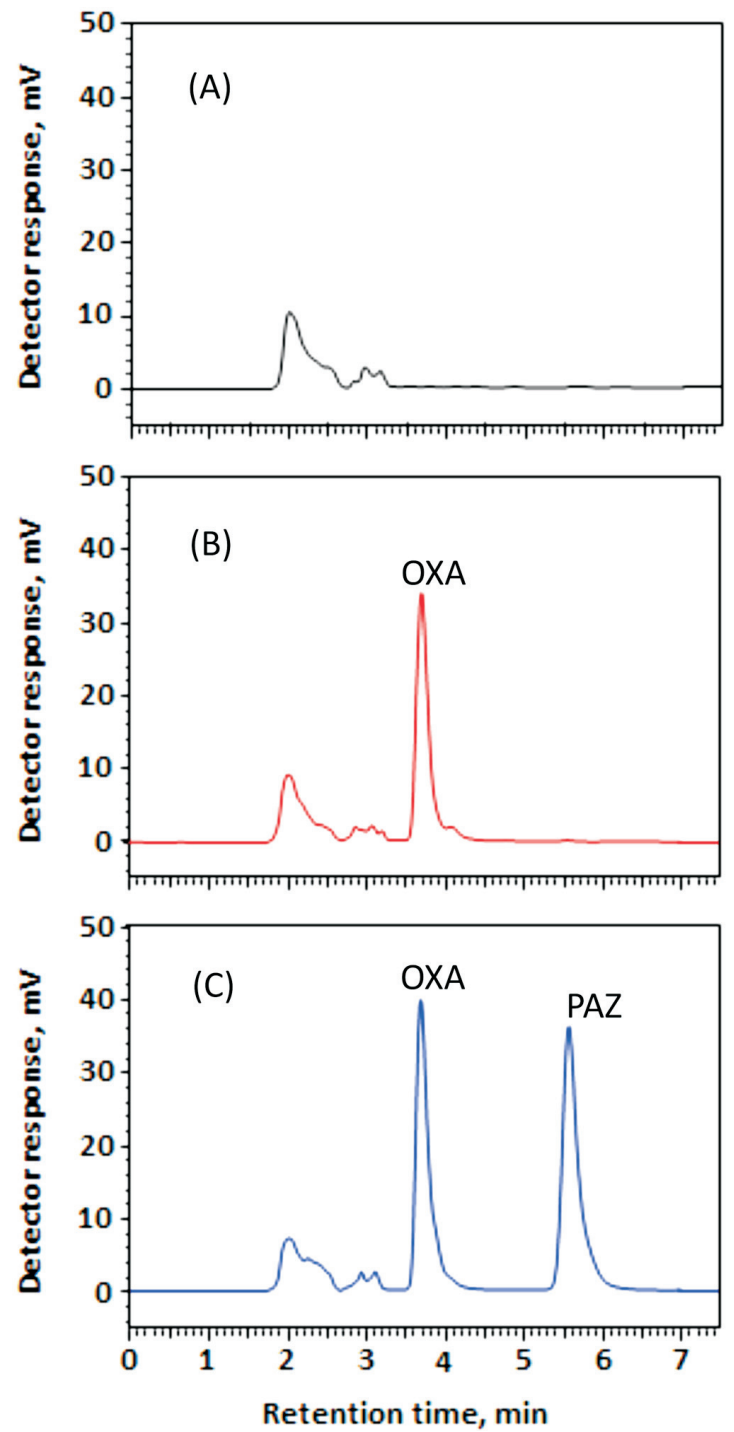

Figure 8 Representative chromatograms from (A) blank PAZ-free human plasma, (B) plasma spiked with internal standard, OXA $\left(5 \mu \mathrm{g} \mathrm{mL}^{-1}\right)$, (C) plasma spiked with OXA $\left(5 \mu \mathrm{g} \mathrm{mL}^{-1}\right)$ and PAZ $\left(5 \mu \mathrm{g} \mathrm{mL}^{-1}\right)$. 
Table 4 Application of the proposed HPLC method in the determination of PAZ in spiked human plasma samples.

\begin{tabular}{ccc}
\hline $\begin{array}{c}\text { Spiked concentration } \\
/ \mu \mathrm{g} \mathrm{mL}^{-1}\end{array}$ & $\begin{array}{c}\text { Measured concentration } \\
/ \mu \mathrm{g} \mathrm{mL}^{-1}\end{array}$ & $\begin{array}{c}\text { Recovery } \\
/ \% \pm \mathrm{RSD}\end{array}$ \\
\hline 4.8 & 4.99 & $103.83 \pm 1.82$ \\
7.2 & 7.21 & $100.17 \pm 4.02$ \\
9.6 & 9.98 & $103.98 \pm 1.81$ \\
12 & 12.26 & $101.62 \pm 3.97$ \\
\hline
\end{tabular}

plasma samples. The stability-indicating property of the method was documented as per the recommendations of $\mathrm{ICH}$ guidelines. In addition, the applicability of the method for determination of PAZ in human plasma samples was proved. From the economical point of view, the method involved the native UV-absorbing property of PAZ, rather than relying on expensive instrumentation as LC-MS/MS. Statistical analysis for the results proved that the method is valid for its routine use in the pharmaceutical quality control industry and clinical laboratories.

\section{Acknowledgement}

The authors would like to extend their appreciation to the Deanship of Scientific Research at King Saud University for its funding of this research through the research group project No. RGP-225.

\section{References}

1 M. S. Moran, Q. Yang, S. Goyal, L. Harris, G. Chung and B.G. Haffty, Evaluation of vascular endothelial growth factor as a prognostic marker for local relapse in early-stage breast cancer patients treated with breast-conserving therapy, Int. J. Radiat. Oncol. Biol. Phys., 2011, 81, 1236-1243.

2 L. Albiges, M. Salem, B. Rini and B. Escudier, Vascular endothelial growth factor-targeted therapies in advanced renal cell carcinoma, Hematol. Oncol. Clin. North Am., 2011, 25, 813-833.

3 B. Berse, L.F. Brown, L. Van de Water, H.F. Dvorak and D.R. Senger, Vascular permeability factor (vascular endothelial growth factor) gene is expressed differentially in normal tissues, macrophages, and tumors, Mol. Biol. Cell, 1992, 3, 211-220.

4 S. Song, A.J. Ewald, W. Stallcup, Z. Werb and G. Bergers, PDGFR $\beta^{+}$perivascular progenitor cells in tumours regulate pericyte differentiation and vascular survival, Nat. Cell Biol., 2005, 7, 870-879.

5 R. Berardi, A. Santinelli, A. Brunelli, A. Onofri, C. Pierantoni, M. Scartozzi, E. Pisa, D. Stramazzotti, P. Mazzanti, L. Zuccatosta, S. Gasparini, A. Sabbatini and S. Cascinu, Epidermal growth factor receptor status in stages of resected non-small cell lung cancer: implications for treatment with epidermal growth factor receptor inhibitors, Anal. Quant. Cytol. Histol., 2011, 33, 196-204.
6 P. Hamberg, J. Verweij and S. Sleijfer, (Pre-) Clinical pharmacology and activity of pazopanib, a novel multikinase angiogenesis inhibitor, Oncologist, 2010, 15, 539-547.

7 Novartis Pharmaceuticals Corporation, Votrient ${ }^{\circledR}$ (pazopanib) tablets; highlights of prescribing information, T2016-48, Revised: June 2016, https://www.pharma.us.novartis.com/sites/www.pharma.us.novart is.com/files/votrient.pdf, retrieved on 4 October 2016.

8 S. Ahuja and K.M. Alsante, Handbook of Isolation and Characterization of Impurities in Pharmaceuticals, Academic Press, San Diego, 2003.

9 S. Ahuja, Impurities Evaluation of Pharmaceuticals, Marcel Dekker, New York, 1998.

10 FDA: Guidance for Industry: Impurities in Drug Product, Draft Guidance, Center for Drug Evaluation and Research (CDER), 1998.

11 W. Grimm, in Drug Stability, Principles and Practices, (J.T. Carstensen and C.T. Rhodes, eds.), Marcel Dekker, New York, 2002, p. 520.

12 H. Khan, M. Ali, A. Ahuja and J. Ali, Stability testing of pharmaceutical products - comparison of stability testing guidelines, Current Pharm. Anal., 2010, 6, 142-150.

13 ICH Guidance for Industry (2000) Q1A (R2): Stability Testing of New Drug Substances and Products, IFPMA, Geneva.

14 K.V. Kumar, K. Puspha and D. Gowri Sankar, Development and validation of stability indicating RP-HPLC method for the determination of pazopanib hydrochloride in bulk drug and its pharmaceutical dosage form, J. Chem. Pharm. Res., 2015, 7, 114-120.

15 G. Ashok, S. Mondal, S. Ganapaty and J. Bandla, Development and validation of stability indicating method for the estimation of pazopanib hydrochloride in pharmaceutical dosage forms by RP-HPLC, Der Pharm. Lett., 2015, 7, 234-241.

16 A. Khan, J.V. Rao, R.P. Pulla, S.K. Sudam and K. Sujana, Estimation of pazopanib hydrochloride in tablet dosage forms by RP-HPLC, Int. J. Adv. Pharm. Anal., 2013, 3, 24-29.

17 V. Escudero-Ortiz, J.J. Pérez-Ruixo and B. Valenzuela, Development and validation of an HPLC-UV method for pazopanib quantification in human plasma and application to patients with cancer in routine clinical practice, Ther. Drug Monit., 2015, 37, 172-179.

18 M. Minocha, V. Khurana and A.K. Mitra, Determination of pazopanib (GW-786034) in mouse plasma and brain tissue by liquid chromatography-tandem mass spectrometry (LC/MS-MS), J. Chromatogr. B., 2012, 901, 85-92.

19 ICH Guideline Q2 (R1): Validation of Analytical Procedure: Text and Methodology, ICH, London, 2005.

20 ICH Guidance for Industry Q1A(R2): Stability Testing of New Drug Substances and Products, ICH Revision 2, November 2003.

21 A. Martin, J. Swarbrick, A. Cammarata and A. Chun, Physical Pharmacy: Physical Chemical Principles in the Pharmaceutical Sciences, 3rd edn., Lea \& Febiger, Philadelphia, 2004, pp. 354-360.

22 R. Kumar, V.B. Knick, S.K. Rudolph, J.H. Johnson, R.M. Crosby, M.C. Crouthamel, T.M. Hopper, C.G. Miller, L.E. Harrington, J.A. Onori, R.J. Mullin, T.M. Gilmer, A.T. Truesdale, A.H. Epperly, A. Boloor, J.A. Stafford, D.K. Luttrell and M. Cheung, Pharmacokinetic-pharmacodynamic correlation from mouse to human with pazopanib, a multikinase angiogenesis inhibitor with potent antitumor and antiangiogenic activity, Mol. Cancer Ther., 2007, 6, 2012-2021. 